\title{
PERBEDAAN PENGETAHUAN ANTARA SUAMI DENGAN IBU PRIMIGRAVIDA TRIMESTER III TENTANG TANDA-TANDA PERSALINAN DI MALANG
}

\section{Knowledge Differences between Husband with Primigravida Trimester III Women about Signs of Labor in Malang}

\author{
Eka Miftakhul Jannah ${ }^{1)}$, Wandi ${ }^{2)}$, Wiwik Agustina ${ }^{3)}$ \\ 1) Pascasarjana Universitas Sebelas Maret \\ 2) Poltekkes Kemenkes Malang \\ 3) STIKes Maharani Malang \\ e-mail: ekamiftakhulj@gmail.com
}

\begin{abstract}
ABSTRAK
Latar belakang: Sangatlah penting bagi suami dan ibu primigravida trimester III mengetahui tanda-tanda persalinan karena kematian ibu pada masa kehamilan maupun saat atau setelah persalinan di dunia masih sangat tinggi hingga saat ini. Penelitian ini bertujuan untuk mengetahui perbedaan pengetahuan antara suami dengan ibu primigravida triemster III tentang tanda-tanda persalinan.

Metode : Desain penelitian yang digunakan analitik observasional dengan pendekatan cross sectional, populasi semua ibu primigravida trimester III dan suami yang periksa di BPM "SR" dengan jumlah 20 orang untuk suami dan 20 orang untuk ibu primigravida trimester III. Teknik sampling menggunakan total sampling. Instrumen penelitian menggunakan kuesioner. Analisis data yang digunakan adalah Uji Mann Whitney dengan SPSS.

Hasil penelitian: Penelitian ini menunjukan bahwa pengetahuan suami dan ibu primigravida trimester III sebagian besar dalam kategori tidak baik dan menurut hasil Uji Mann Whitney terdapat perbedaan pengetahuan antara suami dengan ibu primigravida trimester II tentang tanda-tanda persalinan.

Simpulan: Hal utama yang membedakan pengetahuan antara suami dengan ibu primigravida adalah sumber informasi, didapatkan ibu lebih banyak memperoleh informasi daripada suami. Sebagian besar suami tidak menemani istrinya untuk kunjungan antenatal. Diharapkan suami bisa meluangkan waktu di hari sabtu maupun minggu untuk menemani istrinya untuk kunjungan antenatal.
\end{abstract}

Kata kunci: Ibu primigravida, trimester III, suami, pengetahuan, tanda-tanda persalinan. 


\section{ABSTRACT}

Background: It is very important for husbands and third trimester primigravida women to knew the signs of labor due to maternal deaths during pregnancy or during or after childbirth in the world is still very high to date. The purpose of this research is to determine the difference in knowledge between husband and primigravida triemster III women about signs of labor. Method: The research is observational analytic withapproach cross sectional, the population of all third trimester primigravida women and husbands who were examined at BPM "SR" were 20 people for husbands and 20 for primigravida trimester III. The sampling technique used total sampling. The research instrument used a questionnaire. The data analysis used is thetest Mann Whitney with SPSS.

Results: Shows that the knowledge of husband and third trimester primigravida women is mostly in the bad category and according to thetest results Mann Whitney there is a difference in knowledge between the husband and primigravida trimester II about the signs of labor.

Conclusion: The main thing that distinguishes knowledge between husbands and primigravida mothers is a source of information, where mothers get more information than husbands. Most husbands do not accompany their wives for antenatal visits. It is hoped that the husband can take time on Saturdays and Sundays to accompany his wife for antenatal visits.

Keywords: Primigravida trimester III women, husband, knowledge, signs of labor.

\section{PENDAHULUAN}

Kematian ibu pada masa kehamilan maupun saat atau setelah persalinan di dunia masih sangat tinggi hingga saat ini. Menurut WHO sekitar 830 ibu meninggal disebabkan komplikasi pada masa kehamilan atau persalinan di seluruh dunia setiap hari. Diperkirakan 303.000 ibu meninggal dunia pada tahun $2015^{[1]}$. Ibu meninggal akibat komplikasi selama dan setelah kehamilan dan persalinan. Komplikasi utama yang menyebabkan hampir $75 \%$ kematian ibu adalah perdarahan hebat setelah melahirkan, infeksi setelah melahirkan, tekanan darah tinggi saat hamil (preeklampsi dan eklampsi), komplikasi saat persalinan, dan aborsi yang tidak aman. Tingginya jumlah kematian ibu di beberapa daerah di dunia mencerminkan ketidakadilan dalam akses ke layanan kesehatan, dan menyoroti kesenjangan antara kaya dan miskin. Hampir semua kematian ibu (99\%) terjadi di negara berkembang. Pada tahun 2015 diperkirakan jumlah kematian ibu di kawasan Asia Tenggara yaitu sejumlah 61.000 jiwa, jumlah tersebut terbesar kedua setelah kawasan Afrika yaitu sejumlah 195.000 jiwa ${ }^{[1]}$.

Kementerian Kesehatan Republik Indonesia memiliki standar keberhasilan dalam upaya meningkatkan kesehatan ibu di Indonesia. Salah satu indikator keberhasilan upaya kesehatan ibu adalah Angka Kematian Ibu (AKI). AKI adalah jumlah kematian ibu selama masa kehamilan, persalinan dan nifas yang disebabkan oleh kehamilan, persalinan, dan nifas atau pengelolaannya tetapi bukan karena sebab-sebab lain seperti kecelakaan atau terjatuh di setiap 100.000 kelahiran hidup. Tahun 2015 jumlah angka kematian ibu di Indonesia sebesar 305 jiwa, mengalami penurunan yang signifikan dari tahun $1991^{[2]}$. Upaya untuk mempercepat penurunan angka kematian ibu salah satunya yaitu mengikutsertakan keluarga terutama suami dalam berperan serta dalam Program Perencanaan Persalinan dan Pencegahan Komplikasi (P4K) ${ }^{[3]}$.

Kesiapan baik fisik ataupun mental sangat dibutuhkan oleh ibu dalam menerima kondisi kehamilannya serta 
dalam menghadapi proses persalinan. Selama masa kehamilan seluruh anggota keluarga harus terlibat terutama suami. Peran serta suami berupa dukungan dan kasih sayang dari suami dapat memberikan perasaan nyaman dan aman ketika ibu merasa takut dan khawatir dengan kehamilannya sehingga ibu hamil menjadi lebih siap dalam menghadapi persalinan ${ }^{[4]}$. Ibu hamil trimester III sering terlambat pergi ke fasilitas kesehatan karena kurangnya pengetahuan ibu hamil dan suami tentang tanda-tanda persalinan dan kurangnya persiapan menghadapi persalinan. Akibatnya ibu primigravida mengalami penyulit dalam proses persalinannya ${ }^{[5]}$. Berdasarkan studi pendahuluan di BPM "SR" Kecamatan Jabung Kabupaten Malang, bahwa masih banyak ibu primigravida yang memiliki pengetahuan yang kurang tentang tanda-tanda persalinan dan kurangnya partisipasi suami saat pemeriksaan kehamilan di BPM tersebut. Berdasarkan latar belakang diatas, penulis ingin meneliti "Perbedaan Pengetahuan antara Suami dengan Ibu Primigravida Trimester III tentang Tanda-Tanda Persalinan di BPM "SR" Kecamatan Jabung Kabupaten Malang”.$$
\text { SUBJEK DAN METODE }
$$

Desain penelitian ini adalah analitik observasional dengan pendekatan cross sectional. Populasi dan sampel dalam penelitian ini adalah semua suami dan ibu primigravida trimester III yang periksa di BPM "SR" Kecamatan Jabung Kabupaten Malang pada bulan April Mei 2015 yang terdiri dari ibu primigravida trimester III sejumlah 20 orang dan suami sejumlah 20 orang. Teknik sampling yang digunakan adalah total sampling yaitu dengan menggunakan seluruh populasi menjadi sampel yang memenuhi kriteria inklusi. Lokasi penelitian di BPM "SR" Kecamatan Jabung Kabupaten dan waktu penelitian bulan Desember April-Mei 2015. Instrumen penelitian ini
}

menggunakan kuesioner dengan 20 butir pertanyaan. Analisis data menggunakan Uji Statistik Mann Whitney dengan menggunakan program SPSS for windows versi 16.00. Tingkat kepercayaan yang digunakan adalah $\alpha=$ 0.05 dan dasar pengambilan keputusan Ho diterima apabila $\mathrm{p}>0.05$ dan $\mathrm{Ha}$ diterima apabila $\mathrm{p}<0.05$. Hipotesis penelitian adalah ada perbedaan pengetahuan antara suami dan ibu primigravida trimester III di BPM "SR" Kecamatan Jabung Kabupaten Malang.

$\frac{\text { HASIL }}{\text { Analisis Univariat }}$

Tabel 1 menunjukan bahwa jumlah suami hampir seluruhnya berusia 20-30 tahun yaitu sebanyak $90 \%$ dan jumlah ibu primigravida trimester III sebagian besar berusia 20-30 tahun yaitu sebanyak $70 \%$. Pendidikan suami dan ibu primigravida trimester III sebagian besar yaitu tamat SMA. Menurut pekerjaan responden menunjukan bahwa sebagian besar jumlah suami yang bekerja swasta sebanyak $60 \%$ dan hampir setengahnya ibu primigravida trimester III tidak bekerja sebanyak $45 \%$ dan bekerja swasta sebanyak $40 \%$.

Tabel 2 menunjukan bahwa sumber informasi suami setengahnya dari keluarga yaitu sebanyak $50 \%$ dan hampir setengahnya sumber informasi ibu primigravida trimester II dari teman dan internet yaitu sebanyak $30 \%$ dari teman yang pernah hamil dan melahirkan dan $40 \%$ dari internet.

Tabel 3 menunjukan bahwa pengetahuan suami tentang tanda-tanda persalinan sebagian besar dalam kategori tidak baik yaitu sebanyak $55 \%$ dan pengetahuan ibu primigravida tentang tanda-tanda persalinan hampir setengahnya dalam kategori tidak baik yaitu sebanyak $40 \%$. Dari hasil perbandingan pengetahuan antara suami dan ibu primigravida trimester II, terdapat kecenderungan pengetahuan ibu relatif lebih baik daripada suami. 
Tabel 1. Distribusi Frekuensi Responden Berdasarkan Umur, Pendidikan, dan Pekerjaan

\begin{tabular}{lcccc}
\hline & \multicolumn{2}{c}{ Suami } & \multicolumn{2}{c}{ Ibu Primigravida Trimester III } \\
& Frekuensi & $\%$ & Frekuensi & $\%$ \\
\hline Umur & 0 & 0 & 6 & 30 \\
$<20$ tahun & 18 & 90 & 14 & 70 \\
$20-30$ tahun & 2 & 10 & 0 & 0 \\
$>30$ tahun & 2 & 10 & 1 & 5 \\
Pendidikan & 4 & 20 & 7 & 35 \\
Tamat SD & 14 & 70 & 12 & 60 \\
Tamat SMP & 0 & 0 & 0 & 0 \\
Tamat SMA & 0 & 0 & & \\
Perguruan tinggi & 0 & 0 & 0 & 0 \\
Pekerjaan & 12 & 60 & 2 & 40 \\
Tidak Bekerja & 8 & 40 & 3 & 15 \\
PNS & & & & \\
Swasta & & & & \\
Wiraswasta & & & & \\
\hline
\end{tabular}

Tabel 2. Distribusi Frekuensi Sumber Informasi Responden tentang Tanda-Tanda Persalinan

\begin{tabular}{ccccc}
\hline \multirow{2}{*}{ Sumber Informasi } & \multicolumn{2}{c}{ Suami } & \multicolumn{2}{c}{$\begin{array}{c}\text { Frekuensi } \\
\text { Ibu Primigravida Trimester II } \\
\text { Frekuensi }\end{array}$} \\
& Frekuensi & $\%$ & Frenc & 10 \\
\hline Keluarga & 10 & 50 & 2 & 30 \\
Teman & 1 & 5 & 6 & 5 \\
Kerabat & 2 & 10 & 1 & 10 \\
Televisi & 0 & 0 & 2 & 0 \\
Radio & 0 & 0 & 0 & 40 \\
Internet & 7 & 35 & 8 & 5 \\
Majalah & 0 & 0 & 1 & 0 \\
Koran & 0 & 0 & 0 & 100 \\
Total & 20 & 100 & 20 & \\
\hline
\end{tabular}

Tabel 3 Tabel Silang Perbandingan Pengetahuan antara Suami dengan Ibu Primigravida Trimester III

\begin{tabular}{lcccc}
\hline \multicolumn{1}{c}{ Pengetahuan } & \multicolumn{2}{c}{ Suami } & \multicolumn{2}{c}{ Ibu Primigravida Trimester III } \\
& Frekuensi & $\%$ & Frekuensi & $\%$ \\
\hline Baik & 0 & 0 & 1 & 5 \\
Cukup & 2 & 10 & 6 & 30 \\
Kurang & 7 & 35 & 5 & 25 \\
Tidak baik & 11 & 55 & 8 & 40 \\
Total & 20 & 100 & 20 & 100 \\
\hline
\end{tabular}

Analisis Bivariat

Analisis data bivariat menggunakan Uji Mann Whitney didapatkan nilai $\mathrm{p}=0.03$ maka Ho ditolak. Berdasarkan hasil tersebut diketahui bahwa terdapat perbedaan pengetahuan antara suami dengan ibu primigravida trimester III tentang tanda-tanda persalinan.

Tabel 4. Hasil Uji Mann Whitney

\begin{tabular}{cccc}
\hline $\mathbf{N}$ & $\mathbf{A}$ & $\mathbf{p}$ & Keterangan \\
\hline 40 & 0.05 & 0.03 & Ho ditolak \\
\hline
\end{tabular}




\section{PEMBAHASAN \\ Pengetahuan Suami tentang Tanda- Tanda Persalinan di BPM "SR" Kecamatan Jabung Kabupaten Malang Tahun 2015}

Faktor-faktor yang mempengaruhi pengetahuan antara lain pendidikan, pekerjaan, umur, pengalaman, minat, kebudayaan lingkungan sekitar, dan informasi. Tidak dapat dipungkiri bahwa semakin tinggi pendidikan seseorang, semakin mudah pula mereka menerima informasi, dan pada akhirnya pengetahuan yang dimilikinya akan semakin banyak ${ }^{[6]}$. Sebaliknya, jika seseorang memiliki tingkat pendidikan yang rendah, maka akan menghambat perkembangan sikap orang tersebut terhadap penerimaan informasi dan nilainilai yang baru diperkenalkan.

Berdasarkan hasil penelitian diketahui bahwa sebagian besar pengetahuan suami tentang tanda-tanda persalinan dalam kategori tidak baik yaitu sebanyak 55\%. Hasil penelitian menunjukan sebagian besar responden tidak tahu tentang pengertian persalinan, usia kehamilan yang siap untuk menjalani proses persalinan, macammacam tanda-tanda persalinan yaitu tanda mungkin, awal, dan positif, dan persiapan persalinan. Responden dalam penelitian kali ini adalah seorang suami yang belum pernah mempunyai anak. Sehingga secara alami suami tidak memiliki pengalaman dalam hal proses persalinan istrinya. Sehingga wajar apabila pengetahuan suami tentang tandatanda persalinan tidak baik.

Berdasarkan hasil penelitian diketahui sebagian besar suami berpendidikan tamat SMA sebanyak 70 $\%$, dengan tingkat pendidikan yang lebih tinggi penyerapan informasi akan lebih mudah cerna, oleh sebab itu alangkah baiknya suami mencari informasi tentang tanda-tanda persalinan dari beberapa sumber antara lain keluarga, kerabat, teman, media massa dan media cetak.

Berdasarkan data yang diperoleh sebagian besar suami bekerja swasta yaitu sebanyak $60 \%$, dikarenakan kurangnya waktu dan pekerjaannya banyak suami yang tidak menemani istrinya untuk melakukan kunjungan antenatal ke bidan, oleh sebab itu, pengetahuan suami kurang dalam hal kehamilan. Alangkah baiknya suami meluangkan waktu pada hari sabtu maupun minggu untuk menemani istrinya saat kunjungan kehamilan di bidan, untuk mengetahui perkembangan kehamilan dan KIE yang diberikan oleh bidan.

Pengetahuan Ibu Primigravida tentang Tanda-Tanda Persalinan di BPM "SR" Kecamatan Jabung Kabupaten Malang Tahun 2015

Sebagian besar pengetahuan ibu prmigravida tentang tanda-tanda persalinan sebagian besar dalam kategori cukup $^{[7]}$. Sedangkan dalam penelitian ini, ibu primigravida trimester III memiliki pengetahuan yang tidak baik tentang tanda-tanda persalinan yaitu sebanyak $40 \%$ dan berpengetahuan cukup sebanyak $30 \%$. Hal ini wajar apabila ibu memiliki pengetahuan yang tidak baik tentang tanda-tanda persalinan sebab ibu tidak pernah melahirkan dan tidak memiliki pengalaman dalam hal proses persalinan. Pengetahuan ibu hamil primigravida trimester III mempengaruhi perilaku dalam mempersiapkan persalinannya, dengan pengatahuan yang baik maka ibu hamil terimester III akan lebih siap dalam mempersiapkan persalinan ${ }^{[8]}$.

Berdasarkan data primer penelitian ini ibu hamil berpendidikan tamat SMA sebanyak 60\%, dengan tingkat pendidikan menengah ibu primigravida memungkinkan dapat menyerap pengetahuan maupun informasi yang didapatkan dari orang lain maupun dari media cetak atau media elektronik 
dengan baik. Responden penelitian ini ibu primigravida sebanyak 20 orang, hampir setengahnya ibu ada yang tidak bekerja sebanyak $45 \%$ dan bekerja di perusahaan sebanyak $40 \%$. Di lingkungan kerja secara tidak langsung ibu primigravida yang bekerja memperoleh pengalaman maupun pengetahuan dari rekan kerjanya yang sudah pernah hamil maupun melahirkan, sehingga bisa saling bertukar informasi tentang kehamilan maupun persalinan. Selain dari lingkungan pekerjaan, ibu bisa memperoleh informasi dari keluarga maupun kerabat dekat. Dengan memperoleh informasi sebanyakbanyaknya pengetahuan ibu bisa bertambah meskipun ibu tidak memiliki pengalaman.

Perbedaan Pengetahuan antara Suami dengan Ibu Primigravida Trimester III tentang Tanda-Tanda Persalinan di BPM "SR" Kecamatan Jabung Kabupaten Malang Tahun 2015

Faktor-faktor yang mempengaruhi pendidikan antara lain lain pendidikan, pekerjaan, umur, pengalaman, minat, kebudayaan lingkungan sekitar, dan informasi $^{[6]}$. Berdasarkan hasil uji statistik menggunakan Mann Whitney $U$ Test menjelaskan bahwa ada perbedaan pengetahuan antara suami dengan ibu primigravida trimester III tentang tandatanda persalinan. Hasil penelitian menunjukan bahwa terdapat kecenderungan bahwa ibu primigravida memiliki pengetahuan yang lebih baik dibandingkan dengan suaminya. Pengetahuan ibu hamil lebih baik dibandingkan dengan suami tentang perawatan kehamilan. Meskipun dengan itu secara garis besar terlihat mayoritas suami dan ibu primigravida memiliki pengetahuan yang tidak baik, salah satunya dikarenakan tidak adanya pengalaman dalam menjalani proses persalinan $^{[9]}$.

Hal utama yang membedakan pengetahuan antara suami dengan ibu adalah sumber informasi. Ibu yang sebagian besar tidak bekerja lebih banyak memiliki waktu untuk mencari maupun mendapatkan informasi tentang kehamilan maupun proses persalinan. Informasi diperoleh dari keluarga, tetangga, teman, internet, dan majalah. Dikarenakan kurangnya waktu dan pekerjaannya, banyak suami yang tidak menemani istrinya untuk melakukan kunjungan antenatal ke bidan sehingga pengetahuan suami kurang dalam hal kehamilan. Sebaiknya suami ikut serta dalam kunjungan antenatal bersama istrinya, karena dengan mengetahui perkembangan kehamilan suami bisa menjadi suami siaga, sehingga apabila suatu saat terjadi komplikasi saat kehamilan maupun persalinan suami sudah siap. Dengan demikian suami juga berperan dalam menurunkan angka kematian ibu. Ibu primigravida trimester III yang berpengetahuan baik tentang kondisi kehamilannya akan menurunkan tingkat kecemasan yang dialami. Begitu juga dengan adanya dukungan keluarga yang baik terutama suami, maka ibu hamil semakin merasa dibutuhkan dan merasa nyaman dalam menjalani masa kehamilannya hingga melahirkan ${ }^{[10]}$.

\section{SIMPULAN}

Terdapat perbedaan pengetahuan antara suami dengan ibu primigravida trimester III tentang tanda-tanda persalinan. Dari hasil perbandingan pengetahuan antara suami dan ibu primigravida trimester III tentang tanda-tanda persalinan, terdapat kecenderungan pengetahuan ibu lebih baik daripada suami.

\section{SARAN}

1. Diharapkan hasil penelitian ini dapat menjadi masukan dan kajian pendidikan dalam menyusun kebijaksaaan untuk proses penelitian yang lebih lanjut agar penelitian di tingkat akademi jauh lebih baik.

2. Hendaknya para suami dan ibu lebih meningkatkan lagi pengetahuannya 
tentang tanda-tanda persalinan dan lebih rutin memeriksakan kehamilannya dan lebih banyak mengumpulkan informasi penting dalam hal proses persalinan. Untuk suami diharapakan meluangkan waktu untuk menemani istrinya saat kunjungan antenatal.

3. Diharapkan dapat memberikan program untuk meningkatkan KIE tentang kesehatan ibu hamil dan persiapan persalinan dengan cara melakukan penyuluhan, maupun mengadakan kelas hamil yang diikuti semua ibu hamil dan suami, realisasi pemanfaatan buku KIA untuk semua ibu hamil.

4. Diharapkan untuk penelitian selanjutnya bisa lebih mengembangkan variabel yang akan diteliti, sehingga penelitian akan lebih berkembang.

\section{DAFTAR PUSTAKA}

1. WHO. Maternal Mortality.

Available at:

https://www.who.int/en/news-

room/fact-sheets/detail/maternalmortality; 2018.

2. Kementerian Kesehatan Republik Indonesia. Profil Kesehatan Indonesia Tahun 2017; 2018.

3. Widoyo R. Peningkatan Peran Suami dalam Kesehatan Ibu dan Anak Indonesia. Jurnal Kesehatan Masyarakat Andalas, 9(2), 2015. pp. 63-64.
4) Ayushita L. Super Lengkap Tips Sehat dan Cerdas Seputar Kehamilan dan Persalinan. Yogyakarta: Araska. 2014.

5) Muthoharoh H. Hubungan Pengetahuan Ibu Primigravida dengan Kesiapan Ibu dalam Menghadapi Persalinan di Wilayah Kerja Puskesmas Deket Kabupaten Lamongan. 7(1), 2018 pp. 40-46.

6) Wahit MI. Promosi Kesehatan. Jakarta: Salemba Medika; 2011.

7) Fritasari D. Tingkat Pengetahuan Ibu Hamil Primigravida Tentang TandaTanda Persalinan di BPS Dyah Sumarmo Desa Tanjungsari Kecamatan Banyudono Kabupaten Boyolali. Surakarta; 2013.

8) Montung VL. Hubungan Pengetahuan dengan Perilaku Ibu Hamil Trimester III dalam Persiapan Persalinan. Jurnal Ilmiah Bidan, 4(1); 2016. pp. 44-49.

9) Pruthi N, Bacchani S, Singh V. Knowledge, Attitude, and Practice Regarding Antenatal Care among Husbands Attending Antenatal Clinic in A Tertiary Care Hospital. 3(7); 2016. pp. 1741-1744. doi: http://dx.doi.org/10.18203/23946040.ijcmph20162035.

10) Hernanto FF. Pengetahuan Tentang Kehamilan, Dukungan Keluarga dan Kecemasan Ibu Primigravida Trimester III. Jurnal Psikologi Indonesia, 5(03); 2016. pp. 232-238. 